\title{
Influence of Urban Settlements' Geometry on Outdoor Thermal Conditions and Comfort: A Case Study of Kampung in Surabaya-Indonesia
}

\author{
Ronalmanto Ronalmanto, I Gusti Ngurah Antaryama, Sri Nastiti Nugrahani Ekasiwi \\ Department of Architecture, Institut Teknologi Sepuluh Nopember, Surabaya \\ e-mail:nastiti@arch.its.ac.id
}

\begin{abstract}
In urban areas, especially urban settlements, low thermal comfort at pedestrian height and the high use of building energy are two interrelated conditions. Geometry of built environment is a factor that correlates with thermal conditions of the location and comfort. Understanding how geometry of built environment affects conditions and thermal comfort can be the basis for improving thermal condition as well as increasing thermal comfort. This study examines the influence of urban settlement geometry to thermal conditions and thermal comfort of urban space. An experiment was carried out on ten blocks, consisting of two block models and two orientations: Blocks with Different Height-to-Width Ratio (H / $\mathrm{W}=0.8-1.5-2.3)$ and Blocks with the Same Height-to-Width Ratio but With Different Left-Right Height $(H / W=1.5-1.5 '-1.5$ "), respectively in the North-South and East-West orientation. The ENVI-met 3.1 program was used to simulate the conditions and thermal comfort of the blocks in the hottest day conditions. The results of this study indicate the geometry of the urban settlement influences two factors or thermal environment, i.e., direct solar radiation reception or block irradiation duration and wind speed. Features of the geometry affecting the thermal conditions are angle of the sky opening and block's orientation towards incoming winds. These two features are regarded as the dominant factor influencing the overall thermal conditions and comfort of the settlement blocks. This study also confirms that hight-width $(\mathrm{H} / \mathrm{W})$ ratio as the main parameter governing thermal conditions and comfort of the block.
\end{abstract}

Keywords-Compact Low-Rise, Experimental, Hottest Day Conditions, Low- Lying Tropical Climate Area, PET.

\section{INTRODUCTION}

$\mathbf{I}_{\mathrm{r}}^{\mathrm{N}}$ NTENSIVE city development as a result of the urban population growth rate [1] is known to have an impact on increasing the air temperature in the city, known as UHI [2, $3,4,5]$. This, in turn, has an impact on the decreasing comfort and health of residents, as well as the increased use of building energy [6, 7], especially in residential areas (urban settlements) which are the largest energy user sector [8]. However, the comfort of the occupants and the use of building energy is not only influenced by the condition of the urban macroclimate but also strongly influenced by the micro-environment conditions [9]. For example, in the case of geometry of built environment, each character of the geometry gives a different effect on the microclimate conditions, and thus on the thermal comfort and energy use of buildings. Several studies have been carried out showing this condition, including studies of the relationship between road geometry and thermal conditions [10,11, 12], studies of the relationship between urban geometry and thermal comfort $[13,14,15,16]$, and studies of the relationship between
Table 1.

Data Input on the ENVI-met 3.1 Program on the Hottest Day Conditions of Surabaya

\begin{tabular}{lc}
\hline \hline Start simulation at day (DD.MM.YY) & 22.10 .2015 \\
Simulation period & $06: 00-11: 00(30 \mathrm{~h})$ \\
Wind speed (ablove $10 \mathrm{~m})$ & $3.86 \mathrm{~m} / \mathrm{s}$ \\
Wind direction (North $=0^{\circ}$, East $\left.=90^{\circ}\right)$ & $90^{\circ}$ \\
Initial temperature & $302.95 \mathrm{~K}\left(29.8^{\circ} \mathrm{C}\right)$ \\
Relative humudity (above $2 \mathrm{~m})$ & $66 \%$ \\
Initial temperature inside the building & $302.95 \mathrm{~K}\left(29.8^{\circ} \mathrm{C}\right)$ \\
\hline \hline
\end{tabular}

shapes and or urban morphology with thermal comfort [17, 18].

Kampung (urban village) is a typology of urban settlements especially in Indonesia [19]. As a basis for urban growth in general, kampung are scattered in several places in a city. Likewise, it is found in Surabaya, the kampung are spread out in the Surabaya city area [20]. Location of the kampung is behind buildings that are on the side of the main road, forming a pocket and having irregular building arrangements which vary in density and heights. This study aims to investigate influence of urban village geometry in Surabaya on outdoor thermal conditions and comfort. Results of the study can form a basis for the designers or policymakers of urban development in designing or building urban areas with consideration of environmental thermal conditions, especially in the context of low-rise buildings in informal settlement.

\section{A. Definition of Kampung}

Kampung or urban village, also termed as informal settlement, can be described according to the character of its environment, which is an independent settlement built by its inhabitants without following formal building construction requirements of the government [21]. Another scholar defines urban villages as residential areas within cities that are formed without planning or growing before planning is implemented [19]. Kampung are the character of informal settlements in Indonesia. In general, villages have an irregular arrangement, with varying densities and heights. Kampung is commonly located behind row of buildings that faces urban main road. It forms a pocket in a city and exist in the form of irregular settlement.

\section{B. Thermal Comfort Index}

Thermal comfort index is used to quantify perceptions of thermal conditions. Some indices are made active for certain sizes. However, several other indices are universal, applicable to all climates and seasons. Some of these indices include the Standard Effective Temperature-SET [22], 
The $6^{\text {th }}$ International Seminar on Science and Technology (ISST) 2020

July $25^{\text {th }} 2020$, Institut Teknologi Sepuluh Nopember, Surabaya, Indonesia

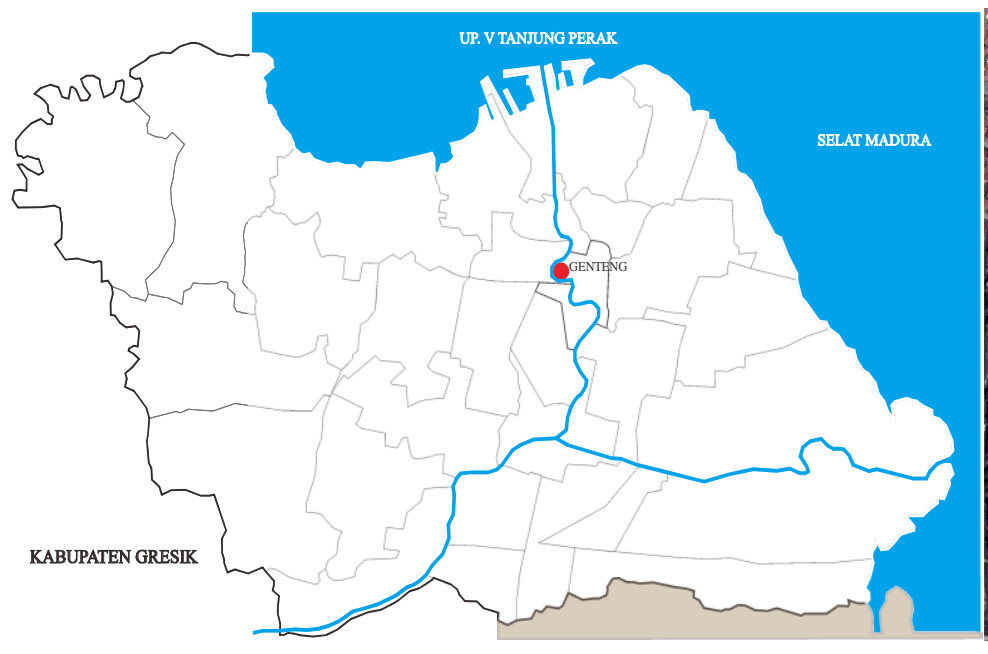

(a)

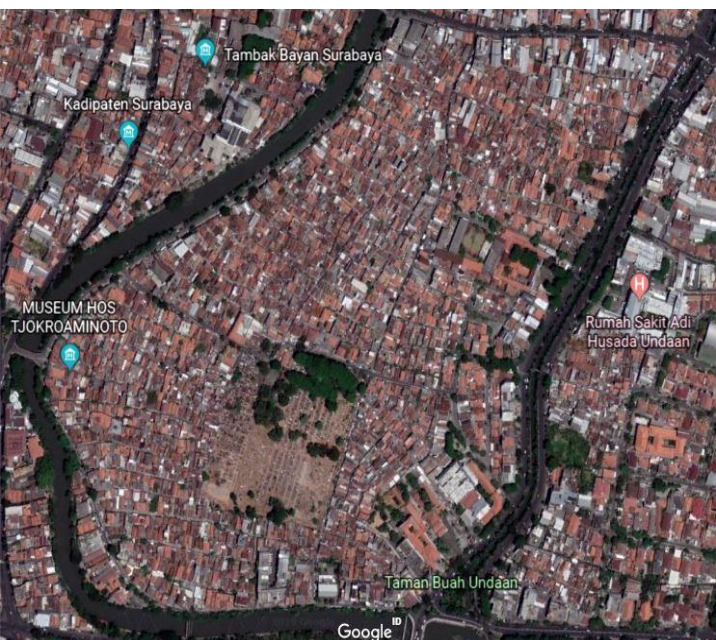

(b)

Figure 1. a) Kampung Peneleh in Genteng District, Cenral of Surabaya City and b) Map of Kampung Peneleh. Source: Google Map, 2019.

OUT_SET [23], Physiological Equivalent Temperature-PET [24] and Universal Thermal Climate Index-UTCI [25]. This study uses PET to measure outdoor thermal comfort of the settlement. In similar studies of this study, PET has been widely used, including in studies conducted by Johansson and Emmanuel (2006) [14], Ali-Toudert and Mayer (2006) [13], and Taleghani et al (2015) [18]. PET is an index based on the Munich Energy-balance Model for Individuals (MEMI) model, which models the thermal conditions of the human body in physiologically relevant ways [24]. PET is expressed in degrees Celsius $\left({ }^{\circ} \mathrm{C}\right)$. In actual calculations, PET is an index translating complex outdoor climate conditions into simple indoor scenarios based on physiological equality that can be easily understood. In this case, PET is defined as air temperature, with a typical room setting $\left(\mathrm{T}_{\mathrm{mrt}}=\mathrm{T}_{\mathrm{a}} ; \mathrm{VP}=\right.$ $12 \mathrm{hPa} ; \mathrm{v}=0.1 \mathrm{~m} / \mathrm{s}$ ), the balance of human body heat is maintained, with the same body and skin temperature. PET is an accurate index for assessing the impact of climate change on human health and well-being [26]. To estimate the degree of PET, $T_{m r t}$ is a very important variable. Radiant heat as a basic parameter of mean temperature radians $\left(\mathrm{T}_{\mathrm{mrt}}\right)$, is a factor closely related to thermal comfort [24][27]. [28][18] revealed that PET is relatively similar to $\mathrm{T}_{\mathrm{mrt}}$.

\section{METHOD}

Experimental methods with simulation techniques were used to analyse influence geometry of the informal settlement on outdoor thermal conditions and comfort. Similar methods have been used in previous studies, including [13][15][17] and [29]. Locus of the study is kampung Peneleh in Surabaya. The study sets the investigation during the hottest day as it represents the most critical conditions in warm-humid tropic.

In this study, the ENVI-met program used as a simulation program. It calculates the mean temperature radians based on a certain height (z). The ENVI-met calculation is based on the calculation of the mean temperature radians outdoors as documented in [13] and used by equation 1 [14][18].

$$
T_{m r t}=\left[\frac{1}{\sigma}\left(\sum_{i=1}^{n} E_{i} F_{i}+\frac{\alpha_{k}}{\varepsilon_{p}} \sum_{i=1}^{n} D_{i} F_{i}+\frac{\alpha_{k}}{\varepsilon_{p}} f_{p} I\right)\right]^{0.25}
$$

\section{Where:}

$E_{i}$ is the long wave radiation $\left(\mathrm{W} / \mathrm{m}^{2}\right)$,

$D_{i}$ is the diffuse and reflected short wave radiation $\left(\mathrm{W} / \mathrm{m}^{2}\right)$,

$F_{i}$ is the angle weighting factor, $I$ is the direct solar radiation $\left(\mathrm{W} / \mathrm{m}^{2}\right)$,

$f_{\mathrm{p}}$ is the surface projection factor,

$\alpha_{k}$ is the absorption coefficient of the irradiated body surface for short wave radiation $(\approx 0.7)$,

$\varepsilon_{p}$ is the emissivity of the human body $(\approx 0.97)$, dan

$\sigma$ is the Stefan-Boltzmann constant $\left(5.6710^{-8} \mathrm{~W} / \mathrm{m}^{2} \mathrm{~K}^{4}\right)$

Equation in the ENVI-met program, $\mathrm{T}_{\mathrm{mrt}}$ at a certain height $(\mathrm{z})$

$$
T_{m r t}=\left[\frac{1}{\sigma}\left(E_{t}(\mathrm{z})+\frac{\alpha_{k}}{\varepsilon_{p}}\left(D_{t}(Z)+I_{t}(Z)\right)\right)\right]^{0.25}
$$

\section{A. Study Area}

Figure 1 mentioned, the present study toke kampung Peneleh in Surabaya as a case study. The city of Surabaya is located in East Java province and lies at 07 09 00 "$07^{\circ} 21^{\prime} 00^{\prime \prime} \mathrm{S}$ and $112^{\circ} 36^{\prime}-112^{\circ} 54^{\prime} \mathrm{E}$. The city experienced warm and humid conditions throughout the year. Kampung Peneleh is located in a dense area and considered as one of the old villages in Surabaya. Buildings in this kampung were atached one another forming a block with their frontages facing street or allay. Pattern of building blocks and street, in general, is a grid pattern with an open space in the middle. Building density in this kampung is around $65.1-80.6 \%$. The kampung is conceived by buildings of 1-3 floors. Ratio of the building height to width of the street ranges between 0.3-1.3.

\section{B. Models of the Settlement Blocks}

Experimental model used in this study is shown in Figure 2. The model is an approximate shape of kampung Peneleh which previously developed in [30]. The experimental model consists of ten blocks, consisting of two block of two different orientations: i) blocks with building of the same heights on either side (i.e., $\mathrm{H} / \mathrm{W}=0.8-1.5-2.3$ ), and ii) blocks with buildings of different height on either side (i.e., $\mathrm{H} / \mathrm{W}=1.5$ - 


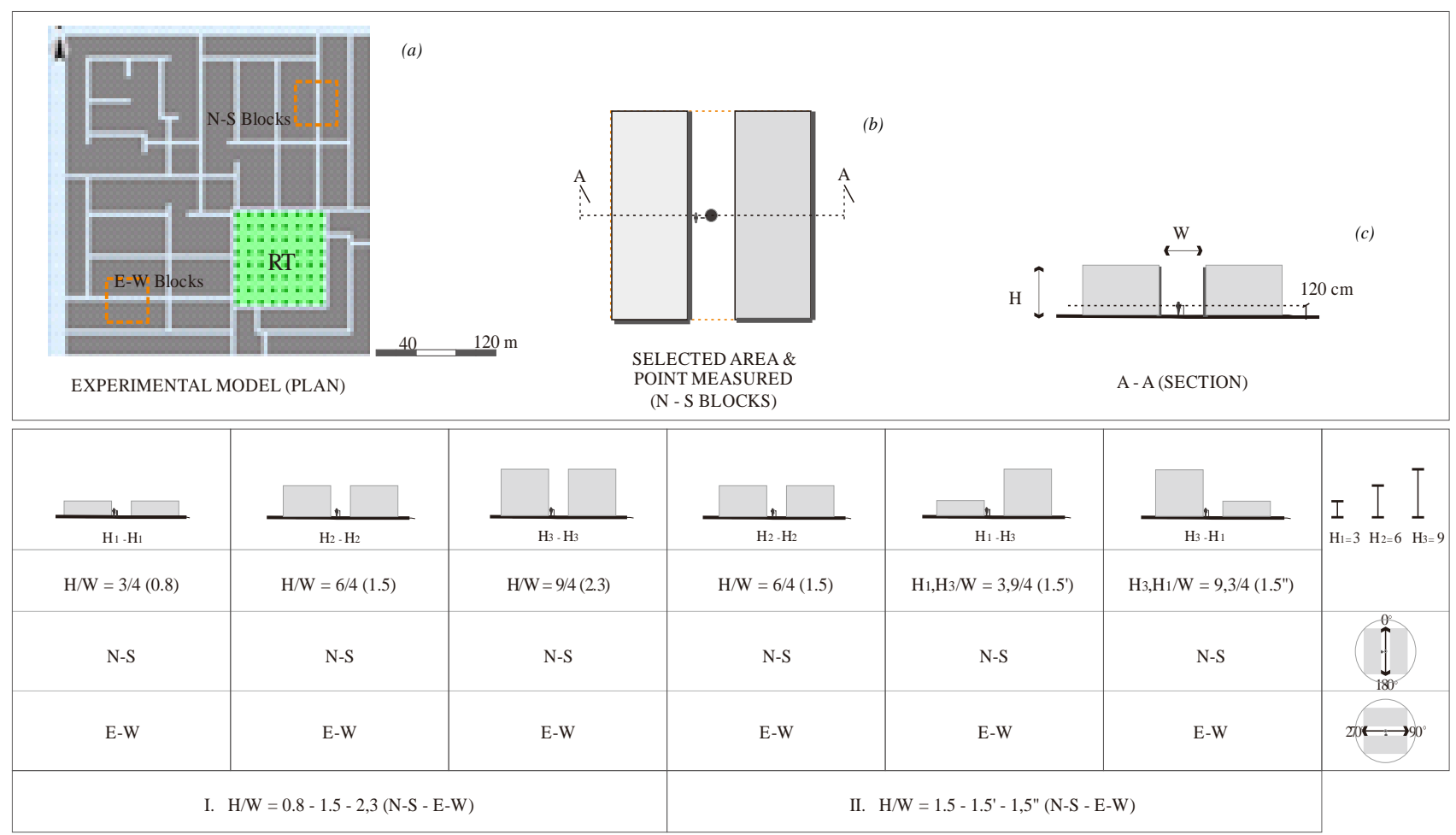

Figure 2. Models considered in the Study: I) Blocks I-NS and EW, and (II) Blocks II-NS and EW.

1.5 '- 1.5' '). Each block oriented both towards North-South and East-West. Simulation of outdoor thermal conditions and comfort in each model were made at one measuring point (b) and at pedestrian height $( \pm 120 \mathrm{~cm})(\mathrm{c})$.

\section{Simulation}

In this study, a simulation is an approach that is carried out to get a picture of outdoor thermal conditions and comfort of the model on the hottest day conditions (October 22). Simulations using the ENVI-met 3.1 program have been carried out on ten blocks such as the experimental model in Figure 2. Before the simulation is carried out, it is necessary to collect the data first, in the form of geographic data (geographic data of Surabaya subjects), climate data (shown in Table 1) and physical data or models. Next, the conditions and comfort data of the simulation results are shown in Figure 3. Specifically for thermal comfort data (PET), extracted from the Bio-Met V1.01 program (explained at the end of this paper) after the simulation.

ENVI-met 3.1 is a program to predict climate conditions well with a three-dimensional display [31]. ENVI-met is the most complete program in terms of human comfort calculations. ENVI-met consists of four main systems, namely soil, vegetation, atmosphere and buildings. The ENVI-met output includes all important meteorological factors, namely air and surface temperature, wind speed and direction, air humidity, mean radiant temperature and shortwave radiation (direct radiation, diffuse radiation, reflected radiation) and longwave radiation (environment radiation). These factors are important factors needed for thermal comfort analysis.

As an urban thermal simulation program or outdoor space, the ENVI-met program has been used in several previous studies. Some of them are research conducted by Ali-Toudert and Mayer (2006) [13], Johansson and Emmanuel (2006)
[14], Ali-Toudert and Mayer (2007) [15], Kruger et al (2011) [16] and Taleghani et al (2015) [18].

\section{Climate Data}

Table 1, climatic data that is used in the ENVI-met 3.1 simulation program is the five-year climatic data of Surabaya between the year of 2010 and 2014. Climatic data were obtained from the Meteorology, Climatology, and Geophysics Agency (BMKG) Perak-1 [32], which is located in the northern part of Surabaya and is approximately $\pm 3,700$ $\mathrm{m}$ away from the Kampung Peneleh.

\section{RESULTS AND DISCUSSION}

\section{A. Data Verification}

Verification was carried out preceded the simulation and fully described in [30]. Results of the verification show that standard deviation between measurement data and simulation result is $4.25{ }^{\circ} \mathrm{C}$ (with min. value 2.5 and $\max .5 .8{ }^{\circ} \mathrm{C}$ ) and correlation value of the two data $\left(\mathrm{R}^{2}\right)$ is 0.91 . The standard deviation is slightly higher than the values stated in [33], which is $2-4{ }^{\circ} \mathrm{C}$. Yet the correlation value is higher than that recommended by [18], which is 0.80 . The simulation result data is relatively lower than that of the measurement, and it results in higher standard deviation value. Some factors may contribute to the higher standard deviation value are low average value of the climate data inputted in the ENVI-met 3.1 program, and mathematical model of the simulation program, which does not take into account heat storage by surface material or envelope. The last factor is noted by [13].

\section{B. Thermal Conditions and Comfort of the Settlement Blocks}

Results of the simulation was illustrated in Figure 3, in which thermal condition and comfort in four models (i.e. 
The $6^{\text {th }}$ International Seminar on Science and Technology (ISST) 2020

July $25^{\text {th }} 2020$, Institut Teknologi Sepuluh Nopember, Surabaya, Indonesia

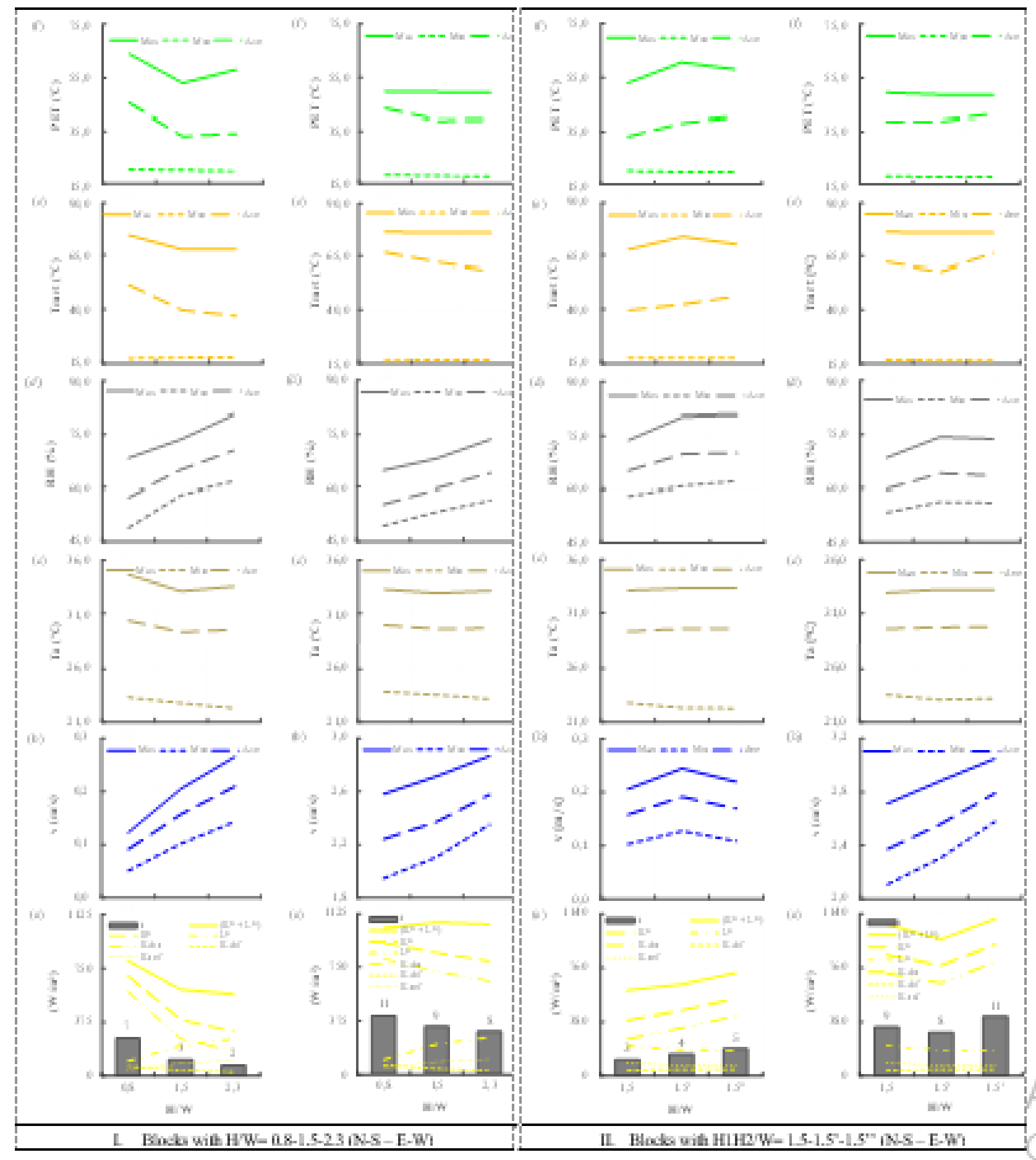

Figure 3. Thermal Conditions and Comfort in the Settlement Blocks: (I) Blocks I-NS and EW, and (II) Blocks II-NS and EW.

models of two different $\mathrm{H} / \mathrm{W}$ groups with two different orientations each). From Figure 3.(I), it can be found that average values of heat gain, win speed (v), and radian temperature $\left(\mathrm{T}_{\mathrm{mrt}}\right)$ in Block I (i.e., $\mathrm{H} / \mathrm{W}=0.8-1.5-2.3$ ) oriented towards East-West (i.e., Block I-EW) are relatively higher than that towards North-South (i.e., Block I-NS). Conversely, other thermal indicators such as air temperature $\left(\mathrm{T}_{\mathrm{a}}\right)$, air relative humidity $(\mathrm{RH})$ and PET tends to be lower in Block I-NS than in Blok I-EW. Similar conditions are also observed in both Block II (H/W = $1.5-1.5$ - 1.5') oriented towards East-West (i.e., Block II-EW) and North-South (i.e., Block II-NS). Figure 3.(II) depicts all these conditions.
Figure 3.(I) shows an increase in ratio of $\mathrm{H} / \mathrm{W}$ in Block IEW and NS will be followed by an increase in $\mathrm{v}$ and $\mathrm{RH}$ and a decrease in heat gain, $T_{a}, T_{m r t}$ and PET. An increase in building height will result in lowering heat gain, temperature and increasing wind speed and air relative humidity at pedestrian level. Magnitude of these conditions help to restore outdoor comfort as indicated by low PET values. Different conditions are noted in Block II, especially in terms of heat gain and wind speed. Heat gain tends to increase as the block is configured by buildings of different hights on either side of the street. When the highest building is located on the west side of the block as in the Block II-NE and on the 
The $6^{\text {th }}$ International Seminar on Science and Technology (ISST) 2020

July $25^{\text {th }} 2020$, Institut Teknologi Sepuluh Nopember, Surabaya, Indonesia

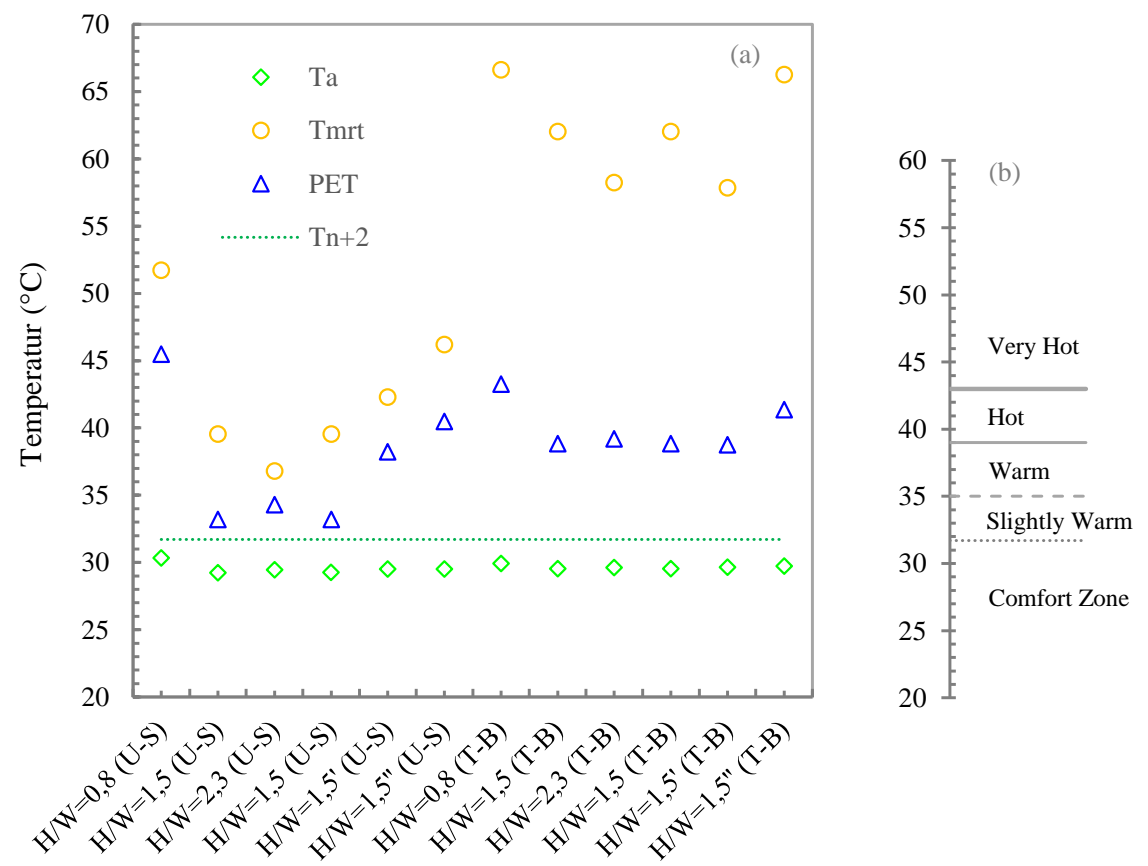

Figure 4. (a) Average Air Temperature ( $\left.\mathrm{T}_{\mathrm{a}}\right)$, Mean Radiant Temperature ( $\left.\mathrm{T}_{\mathrm{mrt}}\right)$ and physiological equivalent temperature (PET) of the Ten Blocks under Study, and (b) Outdoor Thermal Comfort Scale for PET.

north side of the block as in the Blok II-EW, heat gain is higher as compared to other models. Other thermal parameters show similar tendency as that in Block I-EW and NS.

Average thermal conditions and comfort in the whole block are relative high with $\mathrm{T}_{\mathrm{a}}$ ranges between $29.2-30.3{ }^{\circ} \mathrm{C}$, $\mathrm{T}_{\text {mrt }}$ between 36.8-66.6 ${ }^{\circ} \mathrm{C}$, heat load $(\mathrm{K}+\mathrm{L})$ recorded between $571-1107 \mathrm{Watt} / \mathrm{m}^{2}$ with a relatively long duration of irradiation (2-11 hours), and PET between $33.2-45.5^{\circ} \mathrm{C}$. PET values are regarded as falling in a range of comfort, slightly warm to very hot as in Figure 4 [35]. Other thermal indicators, such, wind speed between 0.1 to $2.8 \mathrm{~m} / \mathrm{s}$, and air relative humidity between $55-71 \%$ are favorable from thermal comfort point of view.

\section{Relationships between Geometry and Thermal Conditions and Comfort in the Settlement Blocks}

In relation to thermal conditions that form around a building (micro-climate), previous study has concluded that the resulting outdoor thermal conditions is a function of geometry or building configuration in the environment [34]. On this basis, it is clear, as the study shown, that geometry of the settlements blocks contributed to outdoor thermal condition and comfort of the area. The following paragraphs serve as explanations of relationship between these two factors.

\section{1) Heat load parameter $\left(K^{*}+L^{*}\right)$}

Which is the sum of shortwave radiation $\mathrm{K}^{*}$ (i.e., direct solar radiation/K.dir , diffuse radiation/K.dif and reflected radiation $/ \mathrm{K}_{\text {.ref }}$ ) and accumulation of long waves radiation on the blocks, $L^{*}[30]$. The heat gained by the settlement blocks as illustrated in Figures 3.(I-II).a is directly proportional to duration of irradiation impinging the blocks ( $t$ ) and predominantly influenced by the amount of direct solar radiation (K.dir). Considering the factors, it can be said that angle of the sky opening is a geometrical factor that affects reception of direct solar radiation and duration of irradiation in the settlement blocks as shown in Figure 5. This confirmed findings from similar study by [18].

\section{2) Wind speed (v)}

In the settlement blocks changes significantly with the change in orientation of the blocks with respect to direction of the incoming wind in Figures 3.(I-II).b. Ratio of wind speed of the blocks oriented towards East-West direction (i.e., parallel to the incoming wind direction) and North-South (i.e., perpendicular to the incoming wind direction) are simulated around 13: 1. It follows blocks oriented towards East-West direction will have greater opportunity for restoring comfort comparing to those oriented towards NorthSouth direction. This condition is in line with the conditions revealed by [17][29] who stated that wind speeds tend to be higher when the building blocks are aligned with the direction of the incoming wind (i.e., forming an angle of $\pm 0^{\circ}$ ) as compared to the blocks that are on the side way of or perpendicular to the incoming wind direction (i.e., forming an angle $\geq 45-90^{\circ}$ ). Wind speed in the settlement blocks in general also tends to increase with an increasing in $\mathrm{H} / \mathrm{W}$ ratio as found in Block I and Block II. This means that increasing building heights will result in an increase in wind speed at the pedestrian level. Previous study by [36] also revealed similar results, i.e., wind speed is directly proportional with the $\mathrm{H} / \mathrm{W}$ ratio. Relating the two thermal parameters described above, it is found the two parameters are positively correlated. As the study shows blocks with higher heat loads also tend to have higher wind speeds or vice versa.

\section{3) Similar to heat load}

Two other thermal parameters $\left(\mathrm{T}_{\mathrm{a}}\right.$ and $\left.\mathrm{T}_{\mathrm{mrt}}\right)$ are found to increase in blocks with high $\mathrm{H} / \mathrm{W}$ ratio, high building heights, and in blocks which are oriented along East-West axis as 
The $6^{\text {th }}$ International Seminar on Science and Technology (ISST) 2020

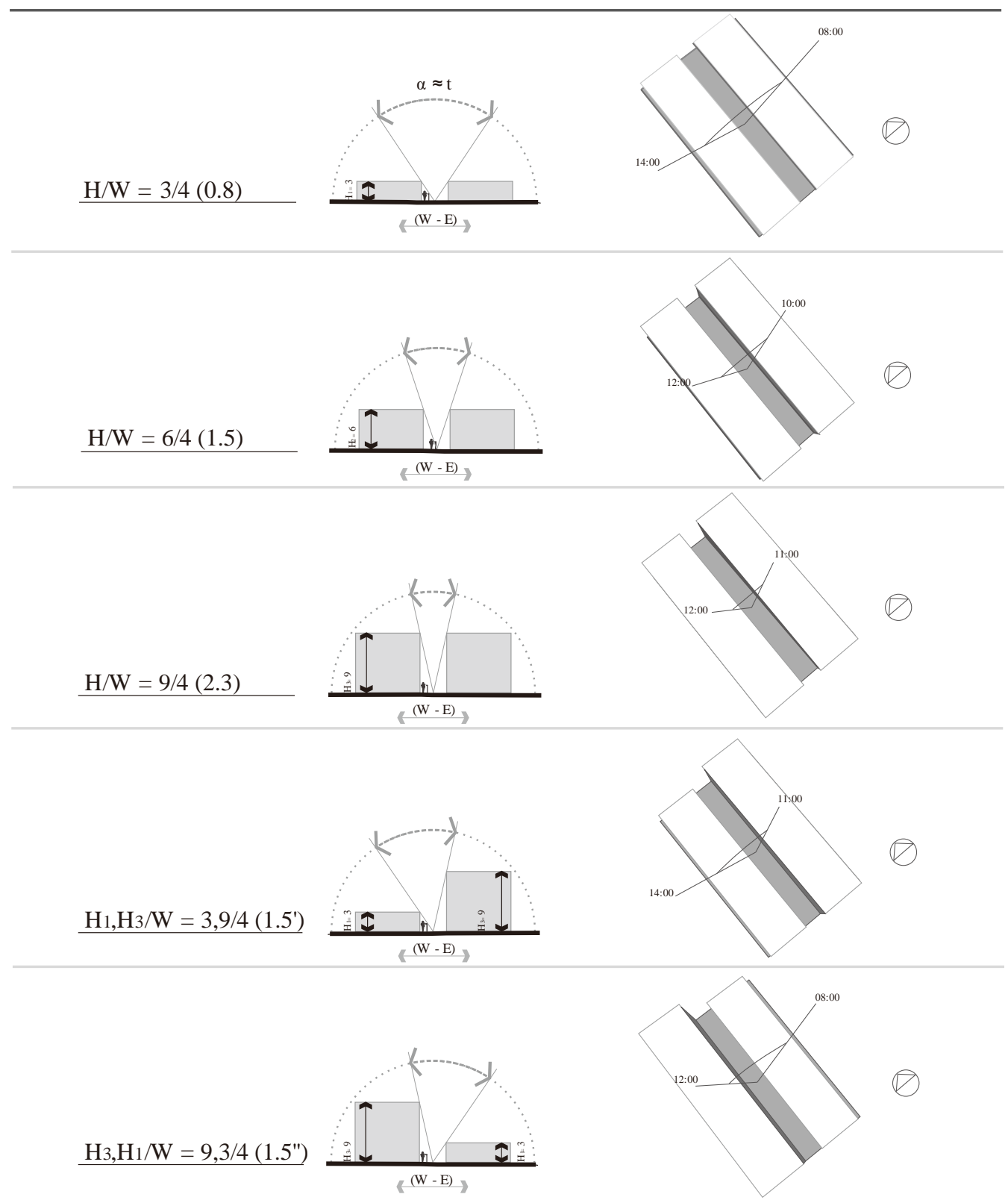

Figure 5. Illustration of the Sky Opening Angle ( $\alpha$ ) of the North-South Blocks (Measured at the Measuring Point) and Duration of Irradiation.

shown in Figures 3.(I-II).c and e. Blocks with higher heat load will have high average $T_{a}$ and $T_{m r t}$. As distinct to these three parameters, PET show slightly different tendency. Figures 3.(I-II).f show PET simulated in the settlement blocks tends to be lower as the wind speed increase. This is particularly evident in the East-West blocks where high wind speeds are commonest.

The above explanation shows that the three thermal parameters considered in the study $\left(\mathrm{T}_{\mathrm{a}}, \mathrm{T}_{\mathrm{mrt}}\right.$ and heat load) will increase in parallel with reception solar radiation and building exposure. This is in line with the study by [13] who revealed that settlement blocks with high $\mathrm{H} / \mathrm{W}$ ratio which lies along North-South orientation will have better thermal conditions as compared to settlements block with low $\mathrm{H} / \mathrm{W}$ ratio and is directed towards East-West orientation. Orienting block towards North-East can have an advantage in terms of heat load as buildings on the east and west can cast shadow over the street [15]. However, it should be noted outdoor thermal comfort is not only influenced by the three factors mentioned above. As the present study found blocks which are oriented towards East-West direction experience lower PET that those lay on North-South orientation. Despite being exposed to direct solar radiation for a long duration, high wind speed is able to suppress the increased thermal conditions in the settlement blocks.

\section{CONCLUSION}

The study concluded that thermal conditions and comfort in the settlement blocks are influenced by geometry of the blocks. H/W ratio, building heights and orientation of the blocks are significantly influence overall outdoor thermal conditions and comfort at pedestrian level. This study are in line with findings obtained in previous studies [10][11][12][13][14][15] [16][17][18][29][36]. Thermal comfort is experienced within the range of slightly-warm to very hot which is indicated by PET between $33.2-45.5{ }^{\circ} \mathrm{C}$. The resulting thermal conditions and comfort on the 
The $6^{\text {th }}$ International Seminar on Science and Technology (ISST) 2020

July $25^{\text {th }} 2020$, Institut Teknologi Sepuluh Nopember, Surabaya, Indonesia

settlement block are greatly affected by reception of direct solar radiation and wind speed. The reception of direct solar radiation in the settlement block is closely related to the angle of the sky opening, while wind speed is affected by orientation of the block.

\section{REFERENCES}

[1] B. Guneralp, R.I. McDonald, M. Fragkias, J. Goodness, P.J. Marcotullio, K.C. Seto, "Urbanization Forecasts, Effects on Land Use, Biodiversity, and Ecosystem Services," in Urbanization, Biodiversity and Ecosystem Services: Challenges and Opportunities, eds. T. Elmqvist, M. Fragkias, J. Goodness, B. Guneralp, P.J. Marcotullio, R.I. McDonald, S. Parnell, M. Schewenius, M. Sendstad, K.C. Seto, C. Wilkinson, London: Springer, pp. 437-452, 2013.

[2] T.R. Oke, "City Size and the Urban Heat Island", Atmospheric Environment, vol. 7, pp 769-779, 1973.

[3] T.R. Oke, Boundary Layer Climates, 2nd Edition, London, Routledge, 1987

[4] A. J. Arnfield, "Two Decades of Urban Climate Research: A Review of Turbulence, Exchanges of Energy and Water, and The Urban Heat Island," International Journal of Climatology, vol. 23, pp 1-26, 2003.

[5] I G.N. Antaryama, S.N.N. Ekasiwi, B.C. Cahyono, FX. T.B.S Samodra, Penataan Bangunan Perumahan Perkotaan untuk Mengurangi Panas Lingkungan Akibat Pemanasan Global di Jawa Timur, Surabaya: ITS, 2010.

[6] M. Davies, P. Steadman, T. Oreszczyn, "Strategies for the Modification of the Urban Climate and the Consequent Impact on Building Energy Use," Energy Policy. vol. 36, pp. 4548-4551, 2008.

[7] Y. Yongling, 'Energy Consumption and Space Density in Urban Area," Energy Procedia, vol. 5, pp. 895-899, 2011.

[8] D. Siswanto, S. Mujiyanto, Suharyati, S H. Pambudi, J L. Wibowo, M. Pratiwi, S. Abdurrahman, Walujanto, Outlook Energi Indonesia 2019, Jakarta: Sekretariat Jenderal Dewan Energi Nasional, 2019.

[9] P. Moonen, T. Defraeye, V. Dorer, B. Blocken, J. Carmeliet, "Urban Physics: Effect of the Micro-climate on Comfort, Health and Energy Demand," Frontiers of Architectural Research, vol. 1, pp. 197-228, 2012.

[10] T.R. Oke, "Canyon Geometry and the Nocturnal Urban Heat Island: Comparison of Scale Model and Field Observations," Journal of Climatology, vol. 1, pp. 237-254, 1981.

[11] T.R. Oke, "Street Design and Urban Canopy Layer Climate", Energy and Buildings, vol. 11, pp. 103-113, 1988.

[12] R.A. Memon, D.Y.C. Leung, C-H. Liu, "Effects of Building Aspect Ratio and Wind Speed on Air Temperatures in Urban-Like Street Canyons," Building and Environment, vol. 45, pp. 176-188, 2010.

[13] F. Ali-Toudert, H. Mayer, "Numerical Study on the Effects of Aspect Ratio and Orientation of an Urban Street Canyon on Outdoor Thermal Comfort in Hot and Dry Climate," Building and Environment, vol. 41, pp. 94-108, 2006.

[14] E. Johansson, Urban Design and Outdoor Thermal Comfort in Warm Climates: Studies in Fez and Colombo, Sweden: Lund University, 2006.

[15] F. Ali-Toudert, H. Mayer, "Effects of Asymmetry, Galleries, Overhanging Facades and Vegetation on Thermal Comfort in Urban Street Canyons," Solar Energy, vol. 81, pp. 742-754, 2007.

[16] E.L. Kruger, F.O. Minella, F. Rasia, "Impact of Urban Geometry on Outdoor Thermal Comfort and Air Quality from Field Measurements in Curitiba, Brazil", Building and Environment, vol. 46, pp. 621-634, 2011.

[17] J. Hang, M. Sandberg, Y. Li, "Effect of Urban Morphology on Wind
Condition in Idealized City Models," Atmospheric Environment, vol. 43, pp. 869-878, 2009.

[18] M. Taleghani, L. Kleerekoper, M. Tenpierik, A.v.d. Dobbelsteen, "Outdoor Thermal Comfort within Five Different Urban Forms in the Netherlands," Building and Environment, vol. 30, pp 1-14, 2015.

[19] A.C. Nugroho, "Kampung Kota sebagai Sebuah Titik Tolak dalam Membentuk Urbanitas dan Ruang Kota Berkelanjutan," Jurnal Rekayasa, vol. 130, pp 209-218, 2009.

[20] Executive Summary Rencana Tata Ruang Wilayah Surabaya, 2015.

[21] J. Silas, W. Setyawan, R. Ernawati, M. Okitasari, Kampung Surabaya Menuju Abad 21, Kajian Penataan dan Revitalisasi Kampung di Surabaya, Surabaya; Badan Perencanaan Pembangunan Kota, 2013

[22] AP. Gagge, AP. Fobelets, LG. Berglund, “A standard Predictive Index of Human Response to the Thermal Environment, ASHRAE, vol. 92, pp. 709-31, 1986.

[23] J. Pickup and R de Dear, "An outdoor thermal comfort index (OUT_SET*) - Part I - the Model and Its Assumptions," In RJ. de Dear, JD. Kalma, TR. Oke, A Auliciems, Sydney, Geneva: World Meteorological Organization; Selected papers from the ICB-ICUC'99 conference, 2000.

[24] P. Höppe, "The Physiological Equivalent Temperature- a Universal Index for the Biometeorological Assessment of the Thermal Environment," Int J Biometeorol, vol. 43, 71-5, 1999.

[25] G. Jendritzky, A. Maarouf, H. Staiger, "Looking for a Universal Thermal Climate Index UTCI for Outdoor Applications," WindsorConference on Thermal Standards, April 5-8, 2001.

[26] A. Matzarakis and B. Amelung, "Physiological Equivalent Temperature as Indicator for Impacts of Climate Change on Thermal Comfort of Humans," in MC. Thomson, HR García, M. Beniston, Seasonal Forecasts, Climatic Change and Human Health, 161 C Springer Science + Business Media B.V, 2008.

[27] S. Thorsson, F. Lindberg, I. Eliasson, B. Holmer, "Different Methods for Estimating the Mean Radiant Temperature in an Outdoor Urban Setting.” Int. J. Climatol, vol. 27, pp.1983-1993, 2007.

[28] H. Mayer, J. Holst, P. Dostal, F. Imbery, D. Schindler, "Human Thermal Comfort in Summer Within an Urban Street Canyon in Central Europe," Meteorologische Zeitschrift, vol. 17, no. 3, pp. 241-250, 2008.

[29] O.S. Asfour, "Prediction of Wind Environment in Different Grouping Patterns of Housing Blocks," Energy and Buildings, vol. 42, pp. 20612069, 2010.

[30] Ronalmanto, I G N. Antaryama, S N N. Ekasiwi, “The Effect of Pattern and Density of the Termal Condition of Urban Settlement Space in Surabaya," Unpublished Thesis, Institut Teknologi Sepuluh Nopember (ITS), Surabaya, 2019.

[31] Bruse, M., (2006), ENVI-met website. http://www.envi-met.com

[32] Badan Meteorologi Klimatologi dan Geofisika Perak-Surabaya, Data Iklim Surabaya 2011-2014

[33] M. Bruse, M. Bürger, A. Bohnstedt, A. Ihde, K. Jesionek, E. Lahme, Measurements and Model Simulations in WP MICRO, RuhrUniversity Bochum, Institute of Geography: Research Group Climatology, 2002.

[34] E. Jamei, P. Rajagopalan, M. Seyedmahmoudian, Y. Jamei, "Review on the Impact of Urban Geometry and Pedestrian Level Greening on Outdoor Thermal Comfort," Renewable and Sustainable Energy Reviews, vol. 54, pp. 1002-1017, 2016.

[35] W. Yang, "Outdoor Thermal Comfort in Urban Spaces in Singapore," PHD Thesis, Singapore: National University. 2004.

[36] F F. Bahar, I G N. Antaryama, S N N. Ekasiwi, "Model of Shading and Urban Landscape in Tropical Urban Termal Environment System, Unpublished Disertation, Surabaya: Institut Teknologi Sepuluh Nopember (ITS), 2017. 